\title{
Ontogeny of brush border carbohydrate digestion and uptake in the chick
}

\author{
David Sklan*, Asaf Geyra, Elad Tako, Orit Gal-Gerber and Zehava Uni \\ Faculty of Agriculture, Hebrew University, PO Box 12, Rehovot, Israel
}

(Received 3 September 2002 - Revised 13 December 2002 - Accepted 16 January 2003)

\begin{abstract}
Ingestion of carbohydrates from the small intestine is the major route of energy supply in animals. In mammals these functions develop both pre- and postnatally and are coordinated for the sucking period. In birds, the physiological requirements are different and hatchlings ingest diets rich in complex carbohydrates soon after hatching. The present study examined the ontogeny of intestinal carbohydrate uptake in the chicken. The expression of mRNA for a brush border enzyme, sucrase-isomaltase (SI), which is critical in disaccharide digestion, was determined, together with that of the $\mathrm{Na}$-glucose transporter (SGLT)-1, which is the major apical glucose transporter, In addition, the homeobox gene cdx, which is involved in inducing SI expression in mammals was examined. It was found that the expression of cdxA mRNA and cdxA protein increased from day 15 of incubation until hatch, after which further changes were small. CdxA protein was shown to bind to the promoter region of SI in the chick indicating that cdxA is similar to the mammalian cdx2. The mRNA of SI was observed at $15 \mathrm{~d}$ incubation, increased from $17 \mathrm{~d}$ of incubation to a peak on day 19 , decreased at hatch and had a further peak of expression $2 \mathrm{~d}$ post-hatch. In contrast, the mRNA of SGLT-1 was not detected until $19 \mathrm{~d}$ of incubation when a major peak of expression was observed followed by a decrease to low levels at hatch and small increases post-hatch. It appears that both SI and SGLT-1 mRNA are expressed before hatch in the chick, but the ontogeny of expression is controlled by different mechanisms.
\end{abstract}

\section{Small intestine: Ontogeny: Carbohydrate: Chick}

Small intestinal assimilation of carbohydrate is fundamental for energy supply in animals. This process is affected by luminal digestion of polysaccharides, brush border digestion of tri- and disaccharides and uptake of glucose to the enterocyte, predominantly by the brush border $\mathrm{Na}$-glucose transporter (SGLT)-1. However, these mechanisms are either not operating or act at very low rates prenatally and develop with different timetables postnatally in different species (Ferraris, 2001).

The adult intestinal phenotype is established following a series of developmental transitions defined by the expression of various specific sets of genes (transcriptosomes) in the individual cells (Traber, 1997). Regulatory transcription relationships in the small intestine have been examined for the brush border carbohydrate-assimilating enzyme sucrase-isomaltase (SI) (Wu et al. 1992; Tung et al. 1997) and lactase-phlorizin hydrolase (Traber, 1997; Fang et al. 2000) in mammals. SI mRNA is first expressed in the mouse at low levels until the sucking-weaning transition (Tung et al. 1997). Transgenic mouse studies have indicated that the patterns of SI expression are regulated by multiple functional cis acting DNA elements (Markowitz et al. 1995; Tung et al. 1997) contained in a 201-nucleotide in the $5^{\prime}$-flanking region of the gene. DNA regulatory elements and associated DNA-binding proteins have been examined in the promotor region (Suh et al. 1994; Wu et al. 1994) and at least three groups of transcriptional proteins have been identified, including caudal-related cdx, hepatocyte nuclear factors and nuclear proteins that interact with a GATA-binding site (Traber, 1997). Studies have indicated that hepatocyte nuclear factor- 1 and cdx 2 (caudal homeobox gene) bind to the SIF3 element of the SI promoter and can partially explain the spatial and temporal regulation of SI expression in the neonatal mouse (Boudreau et al. 2001; Krasinski et al. 2001). Transcription of the lactase-phlorizin hydrolase gene is also activated by cdx2 binding to the promoter region during enterocyte differentiation (Fang et al. 2000); however, the spatial distribution of this and the SI genes along the mature villus differ (Goda et al. 1999).

\footnotetext{
Abbreviations: cdx, homeobox gene of the caudal family; EMSA, electrophoretic mobility shift assay; SGLT, Na-glucose transporter; SI, sucrase-isomaltase.

* Corresponding author: Professor D. Sklan, fax +972 89489865 , email sklan@agri.huji.ac.il
} 
The fetal intestine in mammals expresses SGLT1 mRNA (Ferraris, 2001) and in the rat jejunum lactase activity and SGLT1 activity increased with the lactose load during the sucking period (O'Connor \& Diamond, 1999), but SGLT1 mRNA appears to be little affected by diet and modulation of activity appears to be translational or post-translational (Ferraris, 2001).

Homeobox genes encode nuclear transcription factors involved in patterning and cell differentiation in development of metazoans. These genes regulate molecules involved in cellular interactions, such as cell adhesion molecules and extracellular matrix components (Edelman \& Jones, 1993) and are regulated by other homeobox genes and growth factors (Lorentz et al. 1997). Homeobox genes of the caudal family (cdx) are expressed in early stages of development and generally only remain active in the gastrointestinal tract. In mammals, cdx 1 was the first homeobox gene discovered in endodermal tissues: it exhibits an increasing gradient expression along the longitudinal axis of the gut and is mainly expressed in undifferentiated crypt cells, whereas cdx 2 was found mainly in the villus (Silberg et al. 2000). It appears that cdx2 provokes pleiotropic effects triggering cells towards the phenotype of differentiating enterocytes (Lorentz et al. 1997).

In the chicken, these processes have not been intensively studied. The cdx genes in the chick differ from mammals and two homeobox genes have been described and termed cdxA (Frumkin et al. 1991) and cdxB (Morales et al. 1996); cdxA has $95 \%$ homology to the mouse cdx1 and $\mathrm{cdx} 2$ in the amino acid sequence of the homeobox domain and cdxB has $95 \%$ homology to the amino acid composition of the mouse $c d x 4$. It was assumed that cdxA acted similarly to murine cdx1 (Frumkin et al. 1994) and cdxB to cdx4; however, we have recently shown that cdxA may have a role in enterocyte maturation and that $\operatorname{cdxB}$ is expressed at much later developmental stages than cdx4 (Geyra et al. 2002). In the chicken following hatching, induction of carbohydrate digestion from exogenous complex carbohydrates occurs over several days (Noy \& Sklan, 2001) and lactase-phlorizin hydrolase is not found, or needed, since lactose is not usually fed. However, the ontogeny of the mechanisms of carbohydrate digestion and uptake have not yet been examined in this species.

The present study examines the expression and activity of SI, SGLT1 and cdxA as related to the ontogeny of carbohydrate ingestion in the jejunum of the chick before and after hatch and in addition indicates that cdxA binds to the promoter region of SI in the chick.

\section{Methods \\ Embryos and chicks}

Embryos (Ross $\times$ Ross) from $15 \mathrm{~d}$ of incubation to $7 \mathrm{~d}$ posthatch were obtained from a commercial hatchery (Kvuzat Yavne, Yavne, Israel) from a maternal flock between 40 and 55 weeks in lay, and chicks were obtained at hatch. Twenty embryos or five chicks were sampled at each age. Time of hatch was defined by removing birds from the hatchery trays as they cleared the shell and $20 \mathrm{~mm}$ jejunal segments were taken for further analysis. On hatching, chicks had immediate free access to water and to a commercial starter diet containing $230 \mathrm{~g}$ crude protein $(\mathrm{N} \times 6.25)$ and $56 \mathrm{~g}$ fat $/ \mathrm{kg}$ based on soyabean meal, wheat and maize (Matmor Feedmill, D. N. Evtach, Israel), meeting or exceeding National Research Council (1994) recommendations. All chicks were maintained in temperature-controlled brooders. Chicks were monitored daily for body weight. All procedures were approved by the Animal Care and Welfare Committee of our Institute.

\section{RNA extraction}

Total RNA was isolated (Chomczynski \& Sacchi, 1987) from the jejunal segment using TRI reagent $(10 \mathrm{ml} / \mathrm{g}$ tissue) according to the manufacturer's protocol (MRC Molecular Research Center, Cincinnati, OH, USA).

\section{Preparation of cDNA probes for sucrase-isomaltase,} sodium-glucose transporter-1, cdxA and $\beta$-actin

Two primers were used in a reverse transcriptase-polymerase chain reaction to amplify a $786 \mathrm{bp}$ sequence of the mRNA coding region of the chicken SI gene (Uni, 1998): (forward) 5'-ATGACATCAACAGTGTTCTCTTCAC- $3^{\prime}$ and (reverse) $5^{\prime}$-TCTGTCCATGGTCATGCAAATCTTG-3'.

Two primers were used in a reverse transcriptase-polymerase chain reaction to amplify a $970 \mathrm{bp}$ sequence of the mRNA coding region of the chicken SGLT-1 gene (Gal-Garber et al. 2000): (forward) 5'-TGGCGGGCTTCTACCGCAGCGAG-3' and (reverse) $5^{\prime}$ - CCCGGTAGGTCACCAGTCCCCAG- $3^{\prime}$.

Two primers were used in a reverse transcriptase-polymerase chain reaction to amplify a $189 \mathrm{bp}$ sequence of the mRNA coding region of the cdxA gene (Frumkin et al. 1991): (forward) 5'-GAGGACAAAGGACAAGTACCGGG-3' $3^{\prime}$ and (reverse) 5'-CCTTCCTCTCTTTCGCCCTCCG-3'.

Two primers were used in a reverse transcriptase-polymerase chain reaction to amplify a $241 \mathrm{bp}$ sequence of the mRNA coding region of the $\beta$-actin gene (Huber et al. 1998): (forward) $5^{\prime}-$ AACCCTAAGGCCAACCGTGAAAAG-3' and (reverse) 5'-TCATGAGGTAGTCTGTCAGGT- $3^{\prime}$.

The reverse transcriptase-polymerase chain reaction products were visualized on an agarose $(1.5 \%)$ gel, stained with ethidium bromide, excised from the gel and purified with DNA isolation system (DNA Isolation Kit; Biological Industries, Kibbutz Beit Haemek, Israel). To confirm that the fragments obtained corresponded to the original sequences, fragments were sequenced by automated sequencing using an Applied Biosystem 373A DNA sequencer (Applied Biosystem, Foster City, CA, USA). Nucleic acid sequences were analysed using the GCG suite programs (Devereux et al. 1984).

\section{Northern blot analysis}

For Northern blot analysis, $30 \mu \mathrm{g}$ total RNA, from different ages, was denatured and separated by electrophoresis on agarose (1.5\%)-1.1 M-formaldehyde gel. After 
electrophoresis, RNA was transferred overnight by capillary transfer onto a nylon membrane (Hybond-N; Amersham Pharmacia Biotech, Amersham, Bucks., UK), and then fixed on the membrane by u.v. at $340 \mathrm{~nm}$ for $2 \mathrm{~min}$. The four probes isolated (see earlier) were used for hybridization. The isolated $\beta$-actin cDNA was used to normalize variations in the total RNA loading. The probes were labelled with $\left[{ }^{32} \mathrm{P}\right] \mathrm{dCTP}$ by random priming (Biological Industries). Pre-hybridization was done at $42^{\circ} \mathrm{C}$ for $4 \mathrm{~h}$, hybridization was conducted at $42^{\circ} \mathrm{C}$ overnight and a high-stringency wash $(0.1 \%$ SDS in $0.015 \mathrm{M}$ sodium citrate and $0 \cdot 15 \mathrm{M}$ sodium chloride $(1 \mathrm{ml} / \mathrm{l})$ at $\left.60^{\circ} \mathrm{C}\right)$ was conducted according to the procedures recommended by Amersham for Hybond $\mathrm{N}$ membranes (Amersham Pharmacia Biotech). Blots were exposed for $16 \mathrm{~h}$ at $-80^{\circ} \mathrm{C}$ to Kodak XAR 5 film (Kodak, Rochester, NY, USA) in the presence of an intensifying screen.

\section{Western blot analysis}

Intestinal tissues were sonicated using an ultrasonic cell disrupter (Microson, Farmingdale, NY, USA), clarified by centrifugation and frozen at $-80^{\circ} \mathrm{C}$. Tissues were normalized to protein content. Embryonic or intestinal proteins were subjected to electrophoresis on SDSpolyacrylamide gels and transferred onto nitrocellulose (Schleicher and Schuell, Dassel, Germany). Detection of the cdxA protein was performed after blocking the membrane in $5 \%$ bovine serum albumin in $0.05 \%$ Tween $(30 \mathrm{ml} / \mathrm{l})$ for $4 \mathrm{~h}$. The primary antibody, $6 \mathrm{~A} 4 \alpha \mathrm{cdxA}$ from ascites (Frumkin et al. 1994) was diluted 1:5000 in 5\% bovine serum albumin in $0.05 \%$ Tween $(30 \mathrm{ml} / \mathrm{l})$ and was incubated with the nitrocellulose membrane overnight at $4^{\circ} \mathrm{C}$. The membrane was washed for three times for 15 min each with $5 \%$ bovine serum albumin in $0.05 \%$ Tween, the secondary antibody, antimouse antibody coupled to horseradish (Armoracia rusticana) peroxidase (Amersham Life Sciences, Amersham, Bucks., UK) which was diluted 1:10000 in 5\% bovine serum albumin in $0.05 \%$ Tween, was added and incubated for $50 \mathrm{~min}$ at room temperature. After washing as previously described, the peroxidase reaction was performed with the ECL kit (Amersham Life Sciences) as recommended by the manufacturer. The films were scanned with a high-resolution scanner and Gel-pro densitometer software (version 3.0; Media Cybernetics, Silver Spring, MD, USA) was applied to determine the amount of mRNA or protein in each band. The amount of mRNA or protein is given in arbitrary units.

\section{Electrophoretic mobility shift assay}

In order to elucidate the specific role of cdxA in intestinal gene activation a modification of the electrophoretic mobility shift assay (EMSA) was performed. EMSA is used to detect the interaction of DNA binding proteins with their DNA recognition sequences. The crude nuclear extracts are incubated with a radiolabelled DNA probe. The complexes are separated from the free probe by migration through a non-denaturing polyacrylamide gel, with the complexes migrating more slowly.
Using standard procedures, $250 \mathrm{ng}$ double-stranded oligo was end-labelled with $\left[\gamma^{-}{ }^{32} \mathrm{P}\right] \mathrm{ATP}$ using T4 polynucleotide kinase. The labelled oligo was purified from unincorporated $\left[\gamma^{-}{ }^{32} \mathrm{P}\right] \mathrm{ATP}$ in a final volume of $100 \mu \mathrm{l}$. The oligos were stored at $-20^{\circ} \mathrm{C}$. The oligonucleotide probes used for the SIF1 region were all end-labelled with ${ }^{32}$ P: GTGCAATAAAACTTTATGAGTA, CCACGTTATTTTGAAATACTCAT (Suh et al. 1994). The non-specific probes were (negative control): GGTACTACTTCTAGCTTCGGAA, CCATGATGAAGATCGAAGCCTT.

Equal volumes of each complementary oligo dissolved in water $(300 \mu \mathrm{M})$ were mixed together and heated to $95^{\circ} \mathrm{C}$ for $5 \mathrm{~min}$. The annealed duplex oligo was then diluted further with water to a final EMSA stock concentration of $3 \mu \mathrm{M}$. The oligo stocks were stored at $-20^{\circ} \mathrm{C}$.

\section{Nuclear extract preparation}

Extracts were prepared from $4 \mathrm{~d}$ old chick jejunum. The tissue samples were homogenized. Cells were collected by centrifugation $(500 \mathrm{~g}, 5 \mathrm{~min})$ and resuspended in $1 \mathrm{ml}$ icecold PBS, then transferred to a microfuge tube and pelleted briefly in a bench-top microfuge for $30 \mathrm{~s}$ at maximum speed $\left(10000 \mathrm{~g}, 4^{\circ} \mathrm{C}\right)$. Cell pellets were resuspended in $400 \mu \mathrm{l}$ icecold buffer A (10 mM-4-(2-hydroxyethyl)-1-piperazineethanesulfonic acid $\mathrm{pH} 7 \cdot 9,10 \mathrm{~mm}-\mathrm{KCl}, 0 \cdot 1 \mathrm{~mm}-\mathrm{EDTA}$, $0 \cdot 1$ mM-ethylene glycol- $O,-O^{\prime}$-bis(2-amino-ethyl)- $N, N, N^{\prime}$, $N^{\prime}$-tetraacetic acid, $1 \mathrm{~mm}$-dithiothreitol, $0.5 \mathrm{~mm}$-phenylmethylsulfonylfluoride, $30 \mathrm{~mm}$-diisopropyl-fluorophosphate) and left on ice for $20 \mathrm{~min}$. NP40 solution was added $(25 \mu \mathrm{l}, 100 \mathrm{ml} / \mathrm{l})$ and the sample was vortexed vigorously for $1 \mathrm{~min}$ at $4^{\circ} \mathrm{C}$. The nuclei were pelleted with a $30 \mathrm{~s}$ spin and then transferred to a fresh tube containing $150 \mu \mathrm{l}$ ice-cold buffer C (20 mM-4-(2-hydroxyethyl)1-piperazine-ethanesulfonic acid $\mathrm{pH} 7.9,0.4 \mathrm{M}-\mathrm{NaCl}$, 1 mM-EDTA, 1 mM-ethylene glycol- $O,-O^{\prime}$-bis(2-aminoethyl)- $N, N, N^{\prime}, N^{\prime}$-tetraacetic acid, 1 mM-dithiothreitol, $1 \mathrm{~mm}$-phenylmethylsulfonylfluoride) and vortexed vigorously at $4^{\circ} \mathrm{C}$ for $15 \mathrm{~min}$. The nuclear extracts were cleared by 10 min centrifugation and the supernatant fractions containing the transcription factors were resuspended after desalting in EMSA buffer. A typical EMSA extract gave a protein concentration of $2 \mathrm{mg} / \mathrm{ml}$.

\section{Electrophoretic mobility shift assay super shift}

In a total volume of $9 \mu \mathrm{l}$, containing a fixed amount of protein, the nuclear extract and specific antibodies to cdxA were combined and incubated for $30 \mathrm{~min}$ at room temperature. To this, $1 \mu \mathrm{l}$ loading buffer was added ( 90 mM-EDTA, glycerol $(300 \mathrm{ml} / \mathrm{l})$, xylene cyanol $(0 \cdot 1 \mathrm{~g} / \mathrm{l}))$. The samples were run on an acrylamide $(5 \%)$ gel with $0.25 \mathrm{M}$-Tris-Borate-EDTA buffer at $300 \mathrm{~V}$ at $4^{\circ} \mathrm{C}$. The radioactive gels were stored at $-80^{\circ} \mathrm{C}$ and exposed to a storage phosphor screen.

\section{Statistics}

Least squares means of results are presented from five replicates of four embryos or five chicks after ANOVA as a split plot with time using the general linear models 
procedures of SAS (1986; SAS Institute Inc., Cary, NC, USA). Differences between means were tested using Duncan's multiple range test and significance was $P<0.05$ unless otherwise stated.

\section{Results}

\section{Expression of cdxA $m R N A$ and protein}

Expression of cdxA mRNA relative to $\beta$-actin was low in the embryo at $15 \mathrm{~d}$ of incubation (Fig. 1(A)) and increases in expression were observed from $17 \mathrm{~d}$ of incubation until hatching; post-hatch little further increases in expression were observed. Changes in the concentrations of the cdxA protein with embryonic age are shown in Fig. 1(B) and these increased in parallel with changes in mRNA expression.

\section{Expression of sucrase-isomaltase and sodium-glucose transporter-1 $\mathrm{mRNA}$}

The expression of mRNA for SI and of SGLT1 relative to $\beta$-actin was also determined (Fig. 2). The SI gene was expressed at $15 \mathrm{~d}$ of incubation and relative expression changed little by $17 \mathrm{~d}$ of incubation; however, at $19 \mathrm{~d}$ of incubation a 3-fold increase in expression was observed, and this was followed by a decrease at hatch with a $40 \%$ increase on day 2 post-hatch followed by a decrease to day 3 with little further change by day 7. Expression of mRNA SGLT1 was not detectable at 15 and $17 \mathrm{~d}$ of incubation, but high levels of expression were observed at $19 \mathrm{~d}$. Expression decreased by approximately 10-fold at hatch, after which small increases occurred until $7 \mathrm{~d}$ post-hatch.

\section{Gel-shift assay}

In order to examine whether the SI gene response elements formed specific DNA-protein and DNA-protein-antibody complexes, a gel-shift assay was carried out with chick jejunal nuclear extract (lanes B, C, E and F respectively). The resulting gel is shown in Fig. 3. The SI promoter, jejunal nuclear extract and anti-cdxA antibodies showed a shift in mobility as compared with SI promoter and the nuclear extract, suggesting that cdxA protein interacts with the response element.

\section{Discussion}

The newly hatched chick must make the transition from metabolic dependence on the yolk sac to utilization of

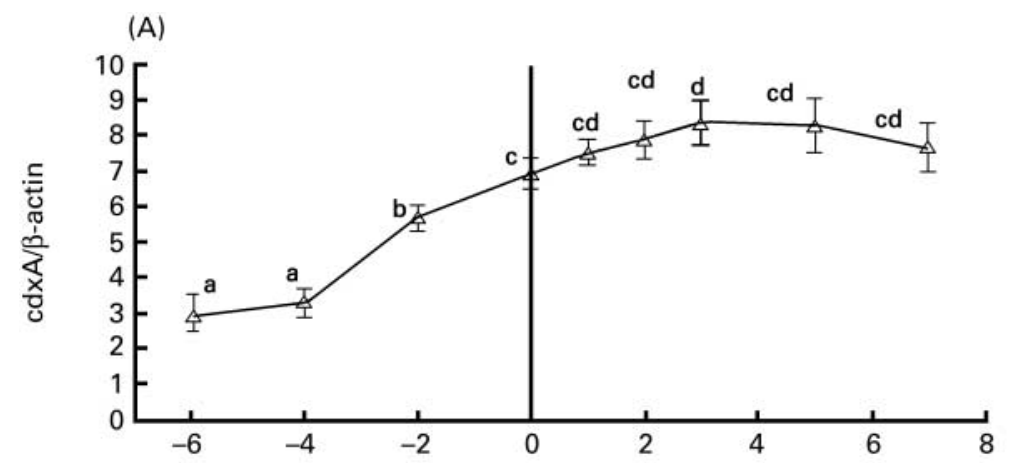

(B)

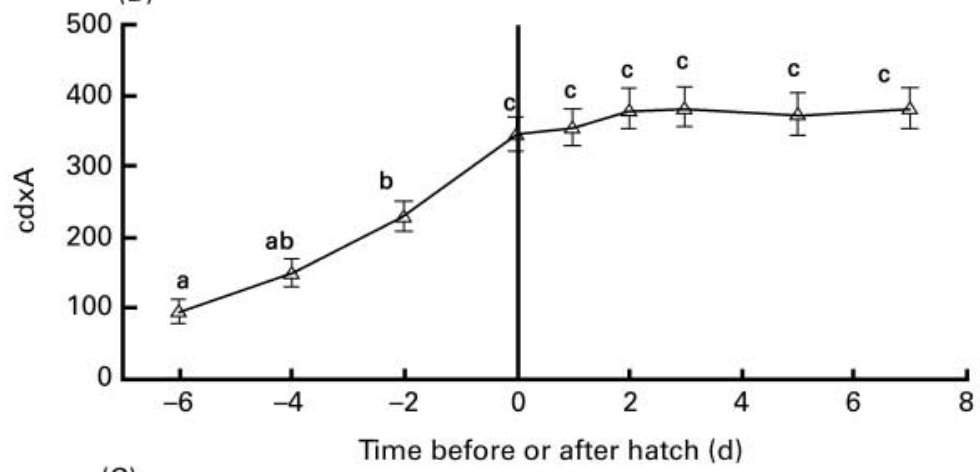

(C)

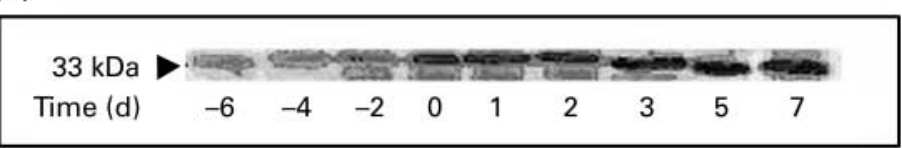

Fig. 1. Expression of $\operatorname{cdxA}$ (homeobox of the caudal family) mRNA (A) and cdx protein $(B)$ and a representative Western blot of the $33 \mathrm{kDa}$ protein (C) from $15 \mathrm{~d}$ of incubation until $7 \mathrm{~d}$ post-hatch. Concentrations of cdx mRNA are normalized to $\beta$-actin mRNA concentrations. For details of procedures, see p. 748. Values are means with their standard errors $(n 5) .{ }^{a, b, c, d}$ Mean values with unlike superscript letters were significantly different $(P<0.05)$. 


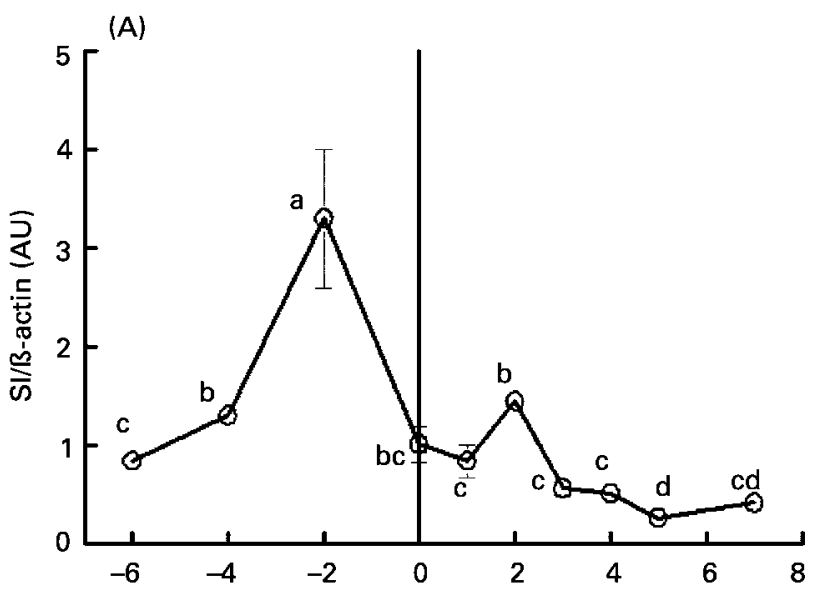

(B)

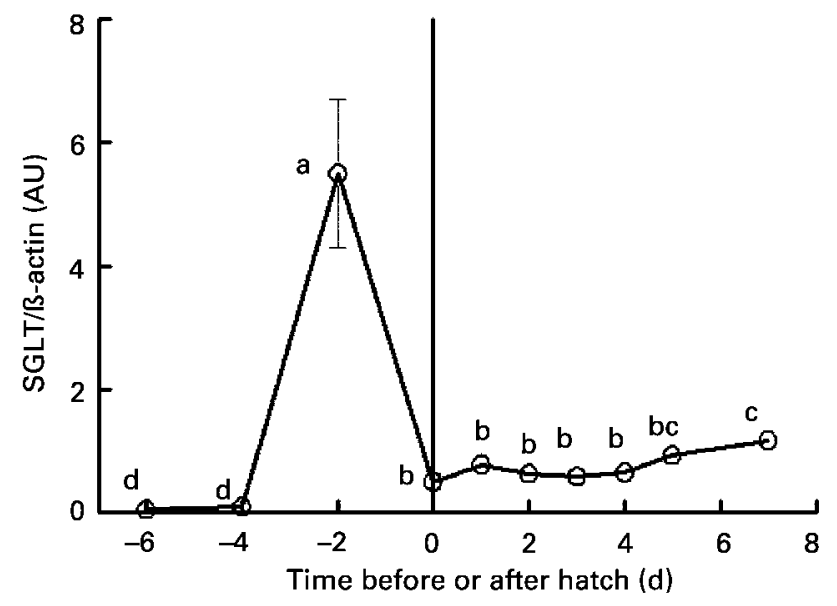

Fig. 2. Expression of sucrase-isomaltase (SI) mRNA (A) and $\mathrm{Na}$-glucose transporter (SGLT)-1 mRNA (B) from 15d incubation until $7 \mathrm{~d}$ post-hatch. Concentrations are normalized to $\beta$-actin concentrations. For details of procedures, see p. 748. Values are means with their standard errors $(n 5)$. ${ }^{a, b, c, d}$ Mean values with unlike superscript letters were significantly different $(P<0.05)$.

exogenous feed rich in carbohydrates. To make this change, the necessary digestive and absorptive mechanisms must be initiated. The present study examined temporal changes in expression of mRNA of two of the major factors involved: SI, an apical membrane-anchored enzyme involved in disaccharide digestion, and SGLT1, the apical membraneanchored glucose transporter. While mRNA expression is not necessarily correlated with protein activity, for SGLT1 activity this appears to be the case (Ferraris \& Diamond, 1997).

In mammals, SI activity is induced by both $\operatorname{cdx} 2$ and other transcription factors binding to the SI promotor region. Lactase-phlorizin hydrolase, which is also involved in intestinal carbohydrate assimilation in mammals, is activated temporally at a similar stage, but differentially by transcription factors (Krasinski et al. 2001). The present study in chickens indicates that cdxA binds to the SI promotor region in a manner similar to the mammalian cdx2. We have recently suggested on the basis of temporal and spatial data that chicken cdxA is similar to mammalian cdx2 (Geyra et al. 2002), rather than cdx1 as originally suggested (Frumkin et al. 1994); the present study indicates similar promoter binding activity. In previous studies expression of cdxA in the chick was found from early embryonic stages, where it participates in axial determination during gastulation (Frumkin et al. 1994; Geyra et al. 2002), and, as shown previously and in the present study, both mRNA and protein concentrations increased in the jejunum with developmental stage, reaching a plateau after hatch. In the mouse intestine, SI is expressed at low levels late in fetal development when the stratified endoderm cells transform into columnar epithelium with nascent villi (Tung et al. 1997). This low level of SI is maintained until 16-17 d postnatally, when rapid increases in expression occur pre-weaning which, together with many other changes in gene expression, result in the phenotype of the adult intestine (Boudreau et al. 2001). In the chicken, development will obviously be different since there is no sucking phase, and complex carbohydrates must be digested and taken up soon after hatch. In the chicken embryo the temporal pattern of SI expression shows activity before hatch and before any carbohydrate is ingested, with a major increase in expression at $19 \mathrm{~d}$ incubation. The present study suggests that the initiation of this transcription is regulated, at least in part, by cdxA, which binds to the SI promoter region and was expressed in increasing quantities during this period. In pre- and postnatal mammals concentrations of mRNA of SI and cdx2 were not correlated (Boudreau et al. 2001), as was also apparent in the present study.

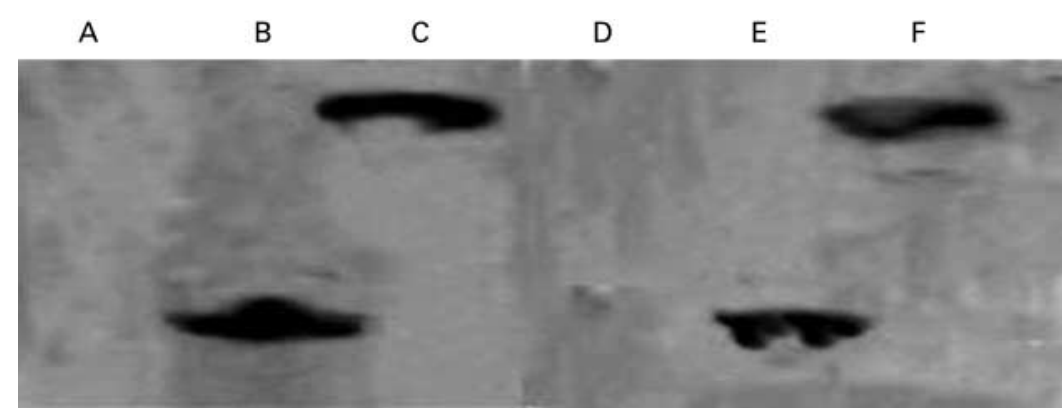

Fig. 3. Gel super-shift mobility assay with anti-cdxA (homeobox of the caudal family) monoclonal antibodies. Lane A, non-specific sequence including nuclear protein extract; lanes B and E, (sucrase-isomaltase (SI) F1 element from SI promoter including nuclear protein extract; lanes C and F, SIF1 element from SI promoter including nuclear protein extract and anti-cdxA monoclonal antibodies; lane D, non-specific sequence including nuclear protein extract and anti-cdxA monoclonal antibodies. For details of procedures, see p. 748. 
In the small intestine of mammals and human subjects, active transport of glucose has been observed in the fetus with brush border glucose transport gradually increasing with gestational age, with a spurt in activity observed in the final stages of gestation (Ferraris, 2001). Expression of SGLT1 in sucking rats is not up-regulated by dietary carbohydrate intake (Jiang \& Ferraris, 2001), although it has been speculated that this lack of regulation may be restricted to enterocytes synthesized neonatally (Ferraris, 2001). Typically, enterocytes containing SGLT1 are observed in the upper portion of the villus and the distribution along the crypt-villus axis may be influenced by the carbohydrate composition of the diet (Ferraris, 2001). SGLT1 expression has not been found to be influenced by cdx in mammals. The major transport of glucose in mammals is by SGLT1; however, GLUT5 is capable of some glucose transport (Ferraris, 2001), whereas in some birds passive transport has been reported to be a major route of transport (Chediack et al. 2001). Expression of SGLT1 mRNA in the developing chick embryo was not detected until $19 \mathrm{~d}$ incubation when a dramatic transient surge in expression was observed, which decreased by hatch, and following ingestion of carbohydrates post-hatch there was a small constant increase in expression until $7 \mathrm{~d}$. This low expression of SGLT1 mRNA close to hatch is consistent with recent studies that have indicated that uptake of glucose was relatively low in hatching chicks and increased gradually post-hatch (Sulistiyanto et al. 1999; Sklan \& Noy, 2000; Noy \& Sklan, 2001). This was attributed in those studies to a possible lack of $\mathrm{Na}$ close to hatch (this $\mathrm{Na}$ is cotransported with glucose by SGLT1) and also to the presence of hydrophobic yolk in the lumen. The present study, however, indicates that low transporter production may limit uptake in the apical membrane in the chick jejunum immediately post-hatch. The pattern of expression of SGLT1 with development is, however, somewhat different from that of SI. Thus the chick, which must assimilate exogenous carbohydrates soon after hatch, expresses both SI and SGLT1 mRNA during the late embryonic stages, but the ontogeny of this process appears to be controlled by different mechanisms. The ability to absorb exogenous carbohydrates changes rapidly post-hatch, but the capacity to absorb glucose may be limited in the immediate post-hatch period by SGLT1 availability.

\section{References}

Boudreau F, Zhu Y \& Traber PG (2001) Sucrase-isomaltase gene transcription requires the hepatocyte nuclear factor-1 (HNF-1) regulatory element and is regulated by the ratio of HNF-1 alpha to HNF-1 beta. Journal of Biological Chemistry 276, 32122-32128.

Chediack JG, Caviedes-Vidal E, Karasov WH \& Pestchanker M (2001) Passive absorption of hydrophilic carbohydrate probes by the house sparrow Passer domesticus. Journal of Experimental Biology 204, 723-731.

Chomczynski P \& Sacchi N (1987) Single step method of RNA isolation by acid guanidium thiocyanate-phenol-choloroform extraction. Analytical Biochemistry 162, 156-159.
Devereux J, Haeberli P \& Smithies O (1984) A comprehensive set of sequence analysis programs for the VAX. Nucleic Acids Research 12, 387-395.

Edelman GM \& Jones FS (1993) Outside and downstream of the homeobox. Journal of Biological Chemistry 268, 20683-20686.

Fang R, Santiago NA, Olds LC \& Sibley E (2000) The homeodomain protein $\mathrm{Cdx} 2$ regulates lactase gene promoter activity during enterocyte differentiation. Gastroenterology 118, $115-127$.

Ferraris RF \& Diamond J (1997) Regulation of intestinal sugar transport. Physiological Reviews 77, 257-302.

Ferraris RP (2001) Dietary and developmental regulation of intestinal sugar transport. Biochemical Journal 360, 265-276.

Frumkin A, Pillemer G, Haffner R, Tarcic N, Gruenbaum Y \& Fainsod A (1994) A role for CdxA in gut closure and intestinal epithelia differentiation. Development 120, 253-263.

Frumkin A, Rangini Z, Ben-Yehuda A, Gruenbaum Y \& Fainsod A (1991) A chicken caudal homologue, CHox-cad, is expressed in the epiblast with posterior localization and in the early endodermal lineage. Development 112, 207-219.

Gal-Garber O, Mabjeesh SJ, Sklan D \& Uni Z (2000) Partial sequence and expression of the gene for and activity of the sodium glucose transporter in the small intestine of fed, starved and refed chickens. Journal of Nutrition 130, 2174-2179.

Geyra A, Uni Z, Gal-Gerber O, Guy D \& Sklan D (2002) Starving affects CDX gene expression during small intestinal development in the chick. Journal of Nutrition 132, 911-917.

Goda T, Yasutake H, Tanaka T \& Takase S (1999) Lactasephlorizin hydrolase and sucrase-isomaltase genes are expressed differently along the villus-crypt axis of rat jejunum. Journal of Nutrition 129, 1107-1113.

Huber PA, Gao Y, Fraser ID, Copeland O, El-Mezgoeldi M, Slatter DA, Keane NE, Marston SB \& Levine BA (1998) Structure-activity studies of the regulatory interaction of the 10 kilodalton C-terminal fragment of caldesmon with actin and the effect of mutation of caldesmon residues 691-696. Biochemistry 37, 2314-2326.

Jiang L \& Ferraris RP (2001) Developmental reprogramming of rat GLUT-5 requires de novo mRNA and protein synthesis. American Journal of Physiology 280, G113-G120.

Krasinski SD, Van Wering HM, Tannemaat MR \& Grand RJ (2001) Differential activation of intestinal gene promoters: functional interactions between GATA-5 and HNF-1 alpha. American Journal of Physiology 281, G69-G84.

Lorentz O, Duluc I, De Arcangelis A, Simon-Assman P, Kedinger M \& Freund JN (1997) Key role of the cdx2 homeobox gene in extracellular matrix-mediated intestinal cell differentiation. Journal of Cell Biology 139, 1553-1565.

Markowitz AJ, Wu GD, Bader A, Cui Z, Chen L \& Traber PG (1995) Regulation of lineage-specific transcription of the sucrase-isomaltase gene in transgenic mice and cell lines. American Journal of Physiology 269, G925-G939.

Morales AV, de la Rosa EJ \& de Pablo F (1996) Expression of the cCdx-B homeobox gene in chick embryo suggests its participation in rostrocaudal axial patterning. Developmental Dynamics 206, 343-353.

National Research Council (1994) Nutrient Requirements of Poultry, 9th ed. Washington, DC: National Academy of Science.

Noy Y \& Sklan D (2001) Yolk and exogenous feed utilization in the posthatch chick. Poultry Science 80, 1490-1495.

O'Connor TP \& Diamond J (1999) Ontogeny of intestinal safety factors: lactase capacities and lactose loads. American Journal of Physiology 276, R753-R765. 
Silberg DG, Swain GP, Suh ER \& Traber PG (2000) Cdx1 and cdx2 expression during intestinal development. Gastroenterology 119, 961-971.

Sklan D \& Noy Y (2000) Hydrolysis and absorption in the small intestines of posthatch chicks. Poultry Science 79, 1306-1310.

Suh E, Chen L, Taylor J \& Traber PG (1994) A homeodomain protein related to caudal regulates intestine-specific gene transcription. Molecular and Cellular Biology 14, 7340-7351.

Sulistiyanto B, Akiba Y \& Sato K (1999) Energy utilisation of carbohydrate, fat and protein sources in newly hatched broiler chicks. British Poultry Science 40, 653-659.

Traber PG (1997) Epithelial cell growth and differentiation. V. Transcriptional regulation, development, and neoplasia of the intestinal epithelium. American Journal of Physiology 273, G979-G981.
Tung J, Markowitz AJ, Silberg DG \& Traber PG (1997) Developmental expression of SI is regulated in transgenic mice by an evolutionarily conserved promoter. American Journal of Physiology 273, G83-G92.

Uni Z (1998) Research notes: Identification and isolation of chicken sucrase-isomaltase cDNA sequence. Poultry Science 77, 140-144.

Wu GD, Chen L, Forslund K \& Traber PG (1994) Hepatocyte nuclear factor-1 alpha (HNF-1 alpha) and HNF-1 beta regulate transcription via two elements in an intestinespecific promoter. Journal of Biological Chemistry 269, $17080-17085$.

Wu GD, Wang W \& Traber PG (1992) Isolation and characterization of the human sucrase-isomaltase gene and demonstration of intestine-specific transcriptional elements. Journal of Biological Chemistry 267, 7863-7870. 